Meta

Journal des traducteurs

Translators' Journal

\title{
Multilingual Technical Dictionary on CD-ROM
}

\section{Walters Lexicon}

Volume 33, numéro 3, septembre 1988

URI : https://id.erudit.org/iderudit/003507ar

DOI : https://doi.org/10.7202/003507ar

Aller au sommaire du numéro

Éditeur(s)

Les Presses de l'Université de Montréal

ISSN

0026-0452 (imprimé)

1492-1421 (numérique)

Découvrir la revue

Citer cette note

Lexicon, W. (1988). Multilingual Technical Dictionary on CD-ROM. Meta, 33(3),

461-462. https://doi.org/10.7202/003507ar d'utilisation que vous pouvez consulter en ligne.

https://apropos.erudit.org/fr/usagers/politique-dutilisation/ 


\section{MULTILINGUAL TECHNICAL DICTIONARY} ON CD ROM

TERMDOK, the database created by the Swedish Centre for Technical Terminology (TNC), is now available on CD ROM. This contains about 25000 single and multiword terms classified into various branches of science and technology, with corresponding terms and synonyms in English, French, German, Danish, Norwegian, Finnish, Russian and Spanish. On the whole there are 100000 equivalences.

The material to TERMDOK, has been taken from about 25 different glossaries published by TNC, within a lot of areas. For example areas as energy, environment, planning and building, workshop engineering, data processing, geology and forestry.

TERMDOK on CD ROM is published by Walters Lexikon in Stockholm. It was produced by Archetype Systems Ltd., of London using the new multilingual CD ROM retrieval soft ware from Dataware $2000 \mathrm{Gmbh}$ in Munich. This Software had rapidly achieved international recognition for its speed of retrieval, ease of use, and facility for tailoring the presentation with prompts and HELP messages appropriate to the language and level selected by the user.

TERMDOK can be of great value for many as technical writers, translators, educators, tutors and librarians. TERMDOK will be updated yearly.

\section{WALTERS LEXICON}

Stockholm, Suède

\section{THE CONTENTS OF THE TERMBANK}

The termbank includes the following glossaries :

Glossary of geology

ca 2500 swe terms : eng, fra, spa, ger, dan, nor, fin Glossary of plastic and rubber terms

ca 2000 swe terms : eng, fra, ger, dan, nor, fin 
Glossary of data processing

ca 1800 swe terms : eng, fra, ger

Glossary of energy

ca 700 swe terms : eng, fra, ger, dan, nor

Glossary of work environment

ca 500 swe terms : eng, fra, ger, dan, nor, fin

Glossary of workshop engineering

ca 1900 swe terms : eng, fra, ger, dan

Glossary of cleaning

ca 300 swe terms : eng, spa, ger, fin

Glossary of textiles

ca 800 swe terms : eng, fra, ger, dan, nor, fin

Glossary of planning and building terms

ca 1000 swe terms : eng, fra, ger

Glossary of paper

ca 1300 swe terms : eng, fra, ger, nor, fin

Glossary of rock engineering

ca 800 swe terms : eng, fra, ger, dan, nor, fin

Glossary of forestry

ca 4600 swe terms : eng

Glossary of glass in building

ca 300 swe terms : eng, fra, ger, dan, nor, fin

Glossary of air treatment

ca 700 swe terms : eng, fra, ger, fin

Glossary of strength of materials

ca 900 swe terms : eng, fra, ger, dan

Glossary of corrosion

ca 500 swe terms : eng, fra, ger, dan, nor, fin

Glossary of water supply and sewerage

ca 800 swe terms : eng, fra, ger, dan, fin

Glossary of waste management

ca 500 swe terms : eng, fra, ger, dan, nor, fin

Glossary of timber construction

ca 700 swe terms : eng, fra, ger, fin

Glossary of geotechnics

ca 500 swe terms : eng, fra, ger

Glossary of heat treatment

ca 300 swe terms : eng, fra, ger

Glossary of nuclear energy

ca 1400 swe terms : eng, fra, ger

Glossary of astronautics

ca 500 swe terms : eng, fra, ger

Glossary of industrial engineering

ca 100 swe terms : eng, ger

Glossary of petroleum

ca 100 swe terms : eng, fra

Glossary of concrete

ca 1300 swe terms : eng, fra, ger, dan, nor, fin 